NBER WORKING PAPER SERIES

USING TAX EXPENDITURES TO ACHIEVE ENERGY POLICY GOALS

Gilbert E. Metcalf

Working Paper 13753

http://www.nber.org/papers/w13753

\author{
NATIONAL BUREAU OF ECONOMIC RESEARCH \\ 1050 Massachusetts Avenue \\ Cambridge, MA 02138 \\ January 2008
}

Erich Muehlegger, Curtis Carlson, and Jay Mackie, provided helpful comments on a preliminary draft. The views expressed herein are those of the author(s) and do not necessarily reflect the views of the National Bureau of Economic Research.

NBER working papers are circulated for discussion and comment purposes. They have not been peerreviewed or been subject to the review by the NBER Board of Directors that accompanies official NBER publications.

(C) 2008 by Gilbert E. Metcalf. All rights reserved. Short sections of text, not to exceed two paragraphs, may be quoted without explicit permission provided that full credit, including $\odot$ notice, is given to the source. 
Using Tax Expenditures to Achieve Energy Policy Goals

Gilbert E. Metcalf

NBER Working Paper No. 13753

January 2008

JEL No. H2,H23,H24,Q42,Q48

\section{ABSTRACT}

Tax expenditures are a major source of support for energy related activities in the federal budget exceeding direct budget support for energy by a factor of nearly six. Focusing on the policy goals of reducing greenhouse gas emissions and petroleum consumption, I find these tax expenditures highly cost ineffective at best and counterproductive at worse. The tax credit for ethanol is an example of a cost ineffective subsidy. The cost of reducing $\mathrm{CO} 2$ emissions through this subsidy exceeded $\$ 1,700$ per ton of $\mathrm{CO} 2$ avoided in 2006 and the cost of reducing oil consumption over $\$ 85$ per barrel.

Gilbert E. Metcalf

Department of Economics

Tufts University

Medford, MA 02155

and NBER

gilbert.metcalf@tufts.edu 


\title{
Using Tax Expenditures to Achieve Energy Policy Goals
}

\author{
Gilbert E. Metcalf*
}

Energy related tax expenditures are an important element of federal budget policy towards energy. Nonna A. Noto (2004) points out that the outlay equivalent for energy tax expenditures in the federal budget in FY 2002 was nearly nine times actual outlays for energy activities in that year, the highest ratio of tax expenditures to outlays for any of the budget functions in that year. ${ }^{1}$ The comparable ratio in FY 2008 is 3.4 though it rises to 5.8 if the ethanol tax credit is included as a tax expenditure. This paper considers the following questions. Can these tax expenditures be justified by important policy goals? If so, are they cost-effective instruments for achieving those goals?

\section{Tax Expenditures for Energy}

Table 1 lists the energy-related tax expenditures for major fuel categories. Not included in Table 1 is the 51థ per gallon Volumetric Ethanol Excise Tax Credit for the use of ethanol in motor vehicle fuels. Technically this is not a tax expenditure, a point I return to below. Including it would add \$3.46 billion in fiscal year 2008 and \$14.17 billion over the period 2008 to 2012.

\footnotetext{
* Department of Economics, Tufts University, Medford, MA, 02155 and National Bureau of Economic Research. Email: gilbert.metcalf@tufts.edu. Erich Muehlegger, Curtis Carlson, and my discussant, Jay Mackie, provided helpful comments.

${ }^{1}$ Strictly speaking one cannot sum tax expenditures due to interactions among them. But the main point would be unaffected were one to make a more accurate measure of all energy tax expenditures taking into account interactions: federal energy policy is driven more by off-budget subsidies than by on-budget spending. This point is only reinforced if one takes into account implicit subsidies such as the PriceAnderson Act for nuclear power.
} 


\begin{tabular}{|c|c|c|}
\hline \multicolumn{3}{|c|}{ Table 1. Energy-Related Tax Expenditures } \\
\hline & 2008 & 2008-2012 \\
\hline \multicolumn{3}{|l|}{ Alternative Fuels } \\
\hline New technology credit & 960 & 5,530 \\
\hline Credit for holding clean renewable energy bonds & 80 & 480 \\
\hline $\begin{array}{l}\text { Other: energy facility bonds, clean-burning } \\
\text { vehicles, fuel cell, microturbine, and solar } \\
\text { investments }\end{array}$ & 400 & 800 \\
\hline Total: Alternative Fuels & 1,440 & 6,810 \\
\hline \multicolumn{3}{|l|}{ Coal } \\
\hline Capital gains treatment of royalties on coal & 170 & 840 \\
\hline Credit for investment in clean coal facilities & 50 & 690 \\
\hline $\begin{array}{l}\text { Partial expensing for advanced mine safety } \\
\text { equipment }\end{array}$ & 20 & 20 \\
\hline Total: Coal & 240 & 1,550 \\
\hline \multicolumn{3}{|l|}{ Energy Conservation } \\
\hline Exclusion of utility conservation subsidies & 110 & 540 \\
\hline $\begin{array}{l}\text { Allowance of deduction for certain energy } \\
\text { efficient commercial building property }\end{array}$ & 170 & 270 \\
\hline $\begin{array}{l}\text { Credit for energy efficiency improvements for } \\
\text { new and existing homes }\end{array}$ & 180 & 210 \\
\hline Total: Energy Conservation & 460 & 1,020 \\
\hline \multicolumn{3}{|l|}{ Oil and Gas } \\
\hline Excess of percentage over cost depletion, fuels & 790 & 3,860 \\
\hline $\begin{array}{l}\text { Expensing of exploration and development costs, } \\
\text { fuels }\end{array}$ & 840 & 2,910 \\
\hline $\begin{array}{l}\text { Other: alternative fuel production credit, partial } \\
\text { expensing for new refinery investment, } \\
\text { accelerated depreciation for certain natural gas } \\
\text { pipelines and other investments }\end{array}$ & 1,110 & 2,550 \\
\hline Total: Oil and Gas & 2,740 & 9,320 \\
\hline $\begin{array}{l}\text { Source: Office of Management and Budget (2007). Amount } \\
\text { Note that tax expenditures should not be summed due to inter } \\
\text { summing is done for illustrative purposes to indicate the relat } \\
\text { expenditures across different fuel sources. }\end{array}$ & ris & $\begin{array}{l}\text { s of dollars. } \\
\text { them. The } \\
\text { of tax }\end{array}$ \\
\hline
\end{tabular}

The first thing to note is that the largest share of tax expenditures for energy goes to the oil and gas industry to encourage domestic production. ${ }^{2}$ Renewables are the

\footnotetext{
2 If the ethanol tax credit were included as a tax expenditure, the renewables category would have the largest share.
} 
second largest. The allocation is imperfect. The largest energy tax expenditure, the new technology credit, is included in the alternative fuels category. This is a collection of investment and production tax credits for renewable power sources (solar power, fuel cells, wind power, etc.). In addition to subsidizing electricity production from renewable sources, credits are available for advanced coal-based projects, refined coal, nuclear power, hydropower, and coal extracted on Indian land. This is the single largest tax expenditure category for energy.

The next two largest tax expenditures are grouped in the oil and gas category. The first is for percentage depletion. As natural resources are extracted from booked reserves, the value of those reserves is diminished. This is a legitimate cost of business and a Haig-Simons income tax would allow a deduction for the value of the resource extracted. Rather than take deductions for the value of the extracted resource, oil, gas, and coal producers are allowed to deduct a fraction of the revenue arising from sale of the resource. Currently percentage depletion is allowed for independent producers at a 15 percent rate for oil and gas and 10 percent for coal. Percentage depletion is allowed on production up to 1,000 barrels of average daily production of oil (or its equivalent for natural gas). In addition, the depletion allowance cannot exceed 100 percent of taxable income from the property (50 percent for coal) and 65 percent of taxable income from all sources.

The third largest item also applies to oil and gas production. Producers may expense intangible drilling expenses (labor and material costs associated with drilling wells). Normally the non-capital expenses associated with oil exploration and drilling would be capitalized and the costs allocated as income is earned from the well over its 
useful life. Corporations may only deduct 70 percent of the costs and must depreciate the remaining 30 percent over five years. Additionally, geological and geophysical costs associated with exploration can be amortized over a two year period. ${ }^{3}$

\section{The Economic Rationale for Energy Tax Expenditures}

I briefly review three arguments for energy-related tax expenditures: energy externalities, national security, and market failures and barriers in energy conservation markets. ${ }^{4}$

A broad array of externalities is associated with our consumption of energy. Burning fossil fuels contributes to air pollution (sulfur dioxides, nitrogen oxides, particulates) and generates greenhouse gases. In addition, our use of petroleum in transportation contributes to roadway congestion, accident externalities, and other traffic related market failures (see Ian Parry and Kenneth A. Small (2005) for a fuller discussion of driving related externalities). Economic theory suggests that we should tax externalities directly. Alternatively one can subsidize clean alternatives to fossil fuels through production and investment tax credits. This is an inefficient way to correct the externality. While the subsidy lowers the price of renewable energy production relative to the price of fossil fuels, it also lowers the price of energy on average and so encourages increased consumption. Moreover the subsidy must be financed with distortionary taxes.

A second broad rationale for government intervention in energy markets is national security concerns. In 2006, the United States imported 66 percent of the 20.6 million barrels per day of the petroleum that it consumed (Energy Information

\footnotetext{
${ }^{3}$ The Energy Independence and Security Act of 2007 extended the period to seven years for the major integrated oil companies.

4 Gilbert E. Metcalf (2007) provides a more in-depth critique of federal energy tax policy.
} 
Administration (2007a)). Reducing oil imports, it is argued, will reduce our vulnerability to unstable governments in the Middle East and other oil rich areas. The difficulty with this argument is that oil is a commodity priced on world markets. Even if the United States were to produce all the oil it consumes, it would still be vulnerable to oil price fluctuations. A supply reduction in the Middle East would raise the price of domestic oil just as readily as it raises the price of imported oil.

Even if the United States were able to reduce its consumption of oil to zero, the United States would not be fully insulated from oil price shocks elsewhere in the world. First, an oil price shock that drives up the price of oil for Europe and China would lead those countries to increase consumption of fuels that substitute for oil. Crops used to produce biofuels would be in greater demand in world markets thereby driving up the price of biofuels. Second, a slowdown in the world economy following a price shock would likely have negative spillover effects for the United States.

A third argument for government intervention in energy markets is the existence of market barriers to energy efficient capital investment. A long-standing "energy paradox" claims that consumers need very high rates of return on energy efficient capital (appliances, housing improvements, lighting, etc.) and a variety of market barriers have been proposed to explain this paradox and to motivate market interventions. ${ }^{5}$ Many have argued that consumers are poorly informed about the potential for energy savings (as well as the value of the savings) associated with new more expensive technologies. This is a reasonable point given the public good nature of information acquisition and suggests the value of government information programs. Programs such as energy efficiency labeling

${ }^{5}$ Gilbert E. Metcalf (2006) critiques this market barriers literature. 
on new appliances can help overcome information failures at low cost. This argument does not, however, justify using the tax system to support these investments.

In summary, it is difficult to justify current energy-related tax expenditures on economic grounds. In fact, policies that encourage increased domestic production of oil and natural gas work at cross-purposes with the goals identified above.

\section{Defining Tax Expenditures}

Tax expenditures are defined as losses in federal revenue arising from provisions of the tax code that allow a credit or deduction or some other exclusion that would not arise in a baseline tax code. Tax expenditures, however, only are counted if they lead to a reduction in corporate or personal income tax receipts. The ethanol tax credit is not officially a tax expenditure because it reduces revenue for the federal motor fuels excise tax rather than the income tax despite the fact that the impact on a business income balance sheet is unaffected by providing the credit against the excise tax or against the income tax. This raises the broader point that the limitation of tax expenditures to income tax reductions is an arbitrary limitation. Only 60 percent of federal receipts come from the personal and corporate income tax. Defining tax expenditures in terms of taxes that comprise less than two-thirds of federal receipts suggests that we are missing potentially important revenue losses elsewhere in the federal budget.

\section{An Economic Assessment of the Ethanol Tax Expenditure}

Are tax expenditures a cost-effective way to achieve our energy goals? Here I present some results for the ethanol tax credit focusing on carbon dioxide $\left(\mathrm{CO}_{2}\right)$ emissions and oil consumption. Table 2 presents information on ethanol and gasoline consumption in 2005 and 2006 as well as $\mathrm{CO}_{2}$ reductions. 
Corn-based ethanol has a modest $\mathrm{CO}_{2}$ emissions impact leading to roughly 13 percent fewer $\mathrm{CO}_{2}$ emissions than gasoline (see studies by Alexander E Farrell et al. (2006) and Jason Hill et al. (2006)). $\mathrm{CO}_{2}$ emissions from gasoline were 1,182 million metric tons in 2005 (Energy Information Administration (2007b)). Given gasoline consumption of 137 billion gallons in 2005 of which 4 billion were ethanol, $\mathrm{CO}_{2}$ emissions were reduced by 4.5 million metric tons. ${ }^{6}$ The increase in ethanol demand in 2006 led to greater emission reductions but the reduction is still small as a percentage of total emissions. Ethanol contributes very little to a reduction in GHG emissions.

\begin{tabular}{|c|c|c|}
\hline & 2005 & 2006 \\
\hline Ethanol Consumption (billion gallons) & 4.0 & 5.4 \\
\hline Gasoline Consumption (billion gallons) & 137 & 142 \\
\hline $\mathrm{CO}_{2}$ Emissions from Gasoline (million tons) & 1182 & 1186 \\
\hline $\mathrm{CO}_{2}$ Emission reductions (million tons) & 4.5 & 5.9 \\
\hline Percentage Reduction in $\mathrm{CO}_{2}$ Emissions & $0.4 \%$ & $0.5 \%$ \\
\hline \multicolumn{3}{|c|}{$\begin{array}{l}\text { Source: Ethanol consumption from Renewable Fuels Association (2007). Gasoline } \\
\text { consumption from Energy Information Administration (2007a). } \mathrm{CO}_{2} \text { emissions from } \\
\text { Energy Information Administration (2007b). See text for description of } \mathrm{CO}_{2} \text { emission } \\
\text { reduction calculation. }\end{array}$} \\
\hline
\end{tabular}

Petroleum consumption is reduced nearly gallon for gallon by substituting ethanol for gasoline. ${ }^{7}$ Thus ethanol use reduced gasoline consumption by just under 3 percent in 2005 and oil consumption more generally by about 1.5 percent. For 2006 the comparable percentage reductions are 3.8 percent and 1.9 percent.

\footnotetext{
6 The emissions per billion gallons of gasoline consumption $(x)$ is given by the solution to the equation $(.87 \mathrm{x})(E)+(G-E) x=$ C where $E$ is ethanol demand, $G$ is gasoline consumption, and $C$ is motor vehicle related carbon dioxide emissions. The reduction in emissions due to ethanol use is then equal to .13Ex. A similar answer is obtained by assuming EIA's estimate that a gallon of gasoline contains 19.5 pounds of $\mathrm{CO}_{2}$.

7 Other energy sources are used to generate ethanol, primarily natural gas and coal in the refining process. Ethanol production can be viewed as a process to convert coal and natural gas into a liquid transportation fuel using corn as an input. In addition, ethanol has less energy content than gasoline. An E10 blend reduces fuel mileage by approximately 3 percent.
} 
How much of the decline in emissions and gasoline consumption can be attributed to the ethanol tax credit? Probably very little. Ethanol demand historically has been driven almost entirely by its use as an oxygenate in reformulated and oxygenated gasoline as well as state mandates for E10. ${ }^{8}$ Adding oxygen to gasoline improves its combustion properties and reduces CO emissions. Starting in 1992 the Clean Air Act Amendments of 1990 required the use of oxygenated gasoline with minimum oxygen levels of 2.7 percent during winter months. This could be achieved by adding Methyl Tertiary Butyl Ether (MTBE) at a 15 percent mix or ethanol at an 8 percent mix. ${ }^{9}$ Most states in the mid-west mandated the use of ethanol as an oxygenate while other states used MTBE.

Subsequent to the introduction of oxygenated gasoline, EPA mandated the use of reformulated gasoline (RFG) in specified non-attainment areas of the country. Unlike oxygenated gasoline, RFG was mandated on a year-round basis. RFG is used in parts of California, much of the eastern seaboard from Virginia up to Southern New Hampshire and a few major metropolitan areas in other parts of the country. ${ }^{10}$ RFG gas must meet a variety of environmental criteria, one of which is a minimum oxygen standard of 2 percent. Historically the two percent standard could be met with ethanol blended at a 5.6 percent rate by volume or with MTBE. Increasingly states are banning MTBE because of concerns over groundwater contamination. As of August 2007 twenty-five states have banned MBTE statewide (Environmental Protection Agency (2007)). Other states have

\footnotetext{
8 The Energy Policy Act of 2005 set annual ethanol use requirements in gasoline beginning FY 2006. I discuss this further below.

9 This information is taken from Erich J. Muehlegger (2004) who provides an excellent description of environmental regulations and their impact on fuel additives.

${ }^{10}$ A map showing current RFG coverage is at http://www.epa.gov/otaq/rfg/whereyoulive.htm.
} 
mandated the use of ethanol as an oxygenate in RFG. ${ }^{11}$ As a result of concerns about potential liability to litigation, the petroleum industry phased out the use of MTBE in refining by mid-2006. Finally, a number of states are beginning to mandate the sale of E10 or gasohol, gasoline blended with 10 percent ethanol. For 2005 only Minnesota had such a mandate in place.

For 2005, I assume that mandated ethanol blended RFG is blended at a 5.6 percent rate and Minnesota mandates E10 for all its gasoline. ${ }^{12}$ Given these state rules, 2.9 billion gallons of ethanol were required in 2005. This estimate is conservative as some states required RFG with ten percent blend rates for ethanol. If the average ethanol blend rate for RFG in 2005 was 7.7 percent then all of the demand for ethanol could be explained by ethanol mandates.

Assume that the remaining demand for ethanol (one-fourth of demand) was attributable to the ethanol tax credit in 2005. What was the 2005 cost of the reduction in $\mathrm{CO}_{2}$ and petroleum consumption from foregone tax revenue? The first column of Table 3 provides the answer. Given the $\mathrm{CO}_{2}$ and petroleum reductions measured in Table 2, we can attribute 1.2 million metric tons of $\mathrm{CO}_{2}$ reductions to the tax credit (26.6 percent of total reductions). At a cost to the U.S. Treasury of over $\$ 2$ billion, the cost of $\mathrm{CO}_{2}$ emissions avoided due to the use of ethanol is over $\$ 1,700$ per ton. A similar calculation shows that the cost of reducing petroleum consumption is $\$ 85$ per barrel. This is the cost to the federal treasury due to lost tax revenue. It does not include the private cost of producing ethanol nor any savings from displaced oil. Note that if the ethanol induced

\footnotetext{
${ }^{11}$ EIA's state energy profiles indicates which states mandate the use of ethanol as an oxygenate.

12 According to the Energy Information Administration, states mandating use of ethanol in RFG in 2005 were Arizona, California, Connecticut, Delaware, Illinois, Indiana, Kentucky, Maryland, Massachusetts, Missouri, Nevada, New Hampshire, New Jersey, New York, Pennsylvania, Rhode Island, Texas, Virginia, and Wisconsin.
} 
by the tax credit is less than one-fourth of total demand, the costs go up considerably. The costs for reductions in $\mathrm{CO}_{2}$ far exceed the price of $\mathrm{CO}_{2}$ emission permits in the $\mathrm{EU}$ Emissions Trading Scheme and any reasonable measure of the marginal damages from carbon emissions. These high costs arise from the large inframarginal aspect of the policy.

The cost of reducing $\mathrm{CO}_{2}$ through the tax credit is quite high even if all ethanol production is driven by the credit. In that case the cost would be over $\$ 450$ per ton $\mathrm{CO}_{2}$, a cost that still exceeds the cost of an EU permit by over a factor of ten. In reality my estimate is likely a lower bound on the cost of reducing $\mathrm{CO}_{2}$ emissions through the tax credit due to my conservative assumptions on mandates.

The second column provides calculations for 2006. The Energy Policy Act of 2005 removed the RFG oxygenate standard and replaced it with mandated amounts of ethanol in gasoline beginning in 2006. The amount required in the first year of the law was 4 billion gallons of ethanol. For the purposes of computing the value of the ethanol credit, I assume that all ethanol produced in excess of the federal blending mandate is due to the tax credit. The cost of $\mathrm{CO}_{2}$ reductions through the tax credit is unchanged. This cost far exceeds any reasonable measure of the marginal damages from carbon emissions. 


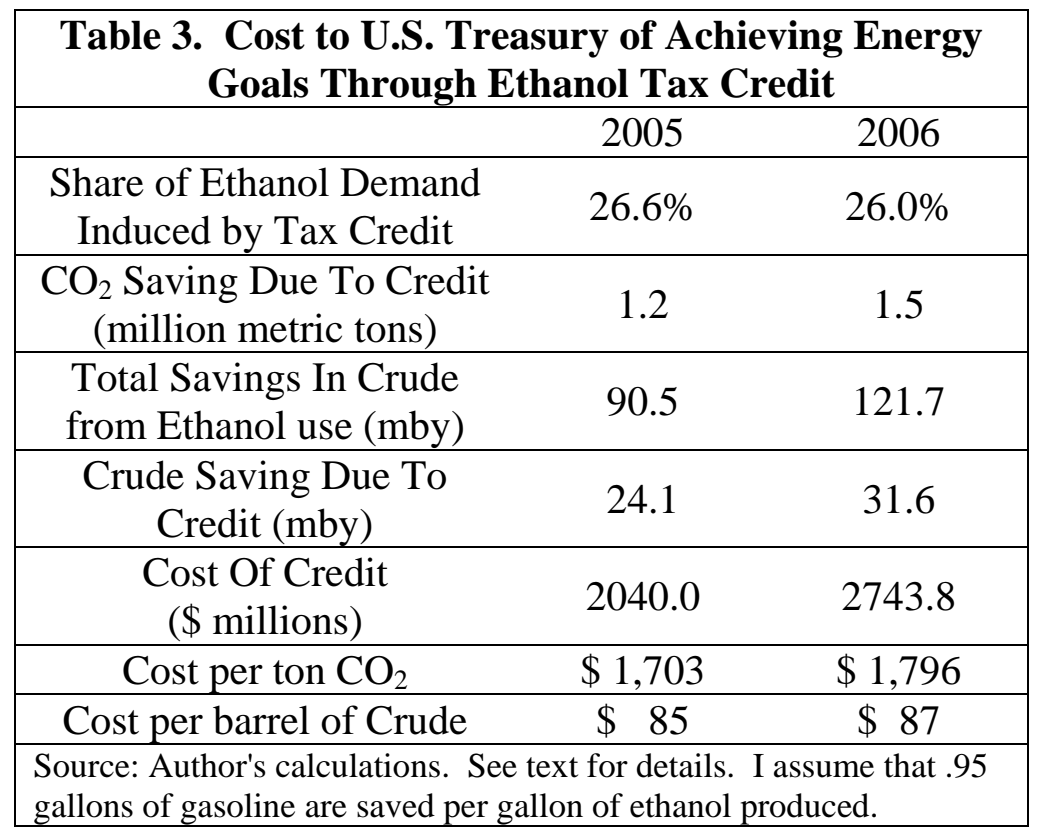

\section{Conclusion}

Tax expenditures for energy provide over seventy-five percent of federal support for energy in this country. It is unlikely that they contribute much to national security goals by reducing petroleum and natural gas consumption. In fact, tax expenditures for the oil and natural gas industry probably contribute to increased consumption of those fuels. These tax expenditures may contribute to a reduction in greenhouse gas emissions through their support for the use of non-carbon based renewable fuels. An examination of the ethanol tax credit, however, suggests that this credit is a particularly expensive policy instrument for reducing $\mathrm{CO}_{2}$ emissions. A better policy would be to replace the credit with a carbon price, either through a cap and trade system or a carbon tax. 


\section{References}

Energy Information Administration. 2007a. Annual Energy Review 2006. Washington, DC: EIA.

DC: EIA.

. 2007b. Emissions of Greenhouse Gases in the United States 2006. Washington,

Environmental Protection Agency. 2007. "State Actions Banning MTBE (Statewide),"

Washington, DC: EPA EPA420-B-07-013.

Farrell, Alexander E; Plevin, Richard J.; Turner, Brian T.; Jones, Andrew D.;

O'Hare, Michael and Kammen, Daniel M. 2006. "Ethanol Can Contribute to Energy and Environmental Goals." Science, 311. 506-08.

Hill, Jason; Nelson, Erik; Tilman, David; Polasky, Stephen and Tiffany, Douglas. 2006. "Environmental, Economic, and Energetic Costs and Benefits of Biodiesel and Ethanol Biofuels." Proceedings of the National Academy of Sciences, 103. 11206-10.

Metcalf, Gilbert E. 2006. "Energy Conservation in the United States: Understanding its Role in Climate Policy," Cambridge, MA: National Bureau of Economic Research No. 12272. 84.

. 2007. "Federal Tax Policy towards Energy." Tax Policy and the Economy, 21. 145-

Muehlegger, Erich J. "Product Differentiation in Gasoline Markets: A Discussion of Regional Gasoline Content Regulations," Cambridge, MA: MIT Department of Economics, 2004.

Noto, Nonna A. 2004. "Tax Expenditures Compared with Outlays by Budget Function: Fact Sheet," Washington, DC: Congressional Research Service RS21710.

Office of Management and Budget. 2007. "Budget of the United States of America, Fiscal Year 2008," Washington, DC: OMB

Parry, Ian and Small, Kenneth A. 2005. "Does Britain or the United States Have the Right Gasoline Tax?" American Economic Review, 95. 1276-89.

Renewable Fuels Association. 2007. RFA Industry Statistics. http://www.ethanolrfa.org/industry/statistics/. (accessed Dec. 10, 2007). 